\title{
Jarosław Centek*
}

\section{Garnizon niemiecki Torunia (1914-1920)}

\author{
German Garrison of Toruń (1914-1920) \\ Die deutsche Garnison in Thorn (1914-1920)
}

\begin{abstract}
Streszczenie. Twierdza Toruń była w 1914 r. jednym z ważniejszych garnizonów na terenie okręgu XVII Korpusu Armijnego. Nic zatem dziwnego, że w 1914 r. w wyniku mobilizacji wyruszyły z niej znaczne siły. W ich miejsce sprowadzono jednostki Landwehry, które miały stanowić jej wojenny garnizon. Jednak wkrótce również i one wyruszyły na front. Wiosną 1915 r. w Toruniu zestawiono dwie dywizje piechoty, a infrastrukturę twierdzy wykorzystywano także do szkolenia obserwatorów lotniczych i artylerzystów. Po klęsce Niemiec w I wojnie światowej tylko część oddziałów wróciła do macierzystego garnizonu, jednakże i tak było to wystarczające, żeby zapobiec jakiejkolwiek zbrojnej próbie opanowania miasta przez Polaków.
\end{abstract}

${ }^{*}$ Badacz historii wojskowej. W latach 1999-2004 studiował historię na Uniwersytecie Mikołaja Kopernika, w ramach programu „Socrates” przedostatni semestr spędził na Universität Potsdam. Następnie, w latach 2004-2008 odbył studia doktoranckie, które uwieńczyła obrona dysertacji „Reichsheer 1921-1926. Organizacja, uzbrojenie, umundurowanie i wyszkolenie", przygotowanej pod kierunkiem prof. dr. hab. Waldemara Rezmera. W 2016 r. uzyskał stopień doktora habilitowanego. W swoich badaniach zajmuje się I wojną światową, historią wojskową okresu międzywojennego, a także wojnami izraelsko-arabskimi. Autor pięciu monografii, podręcznika do szkoły średniej oraz około 100 artykułów. Część jego publikacji dostępna jest w sieci Internet: https://torun-pl.academia.edu/JaroslawCentek. ORCID: 0000-0001-8903-8440. 


\begin{abstract}
In 1914, the Torun Fortress was one of the most important garrisons in the district of the 17th Army Corps. Not surprisingly, in 1914, as a result of the mobilisation, considerable forces set out from it. Landwehr units were brought instead, which were to be the military forces' war garrison. However, they also soon went to the front. In the spring of 1915, two infantry divisions were formed in Torun, and the fortress infrastructure was also used to train air observers and artillerymen. After Germany had been defeated in World War I, only some of the troops returned to their parent garrison, but it was enough to prevent any armed attempt to capture the city by Poles.
\end{abstract}

Zusammenfassung. Die Festung Thorn war 1914 eine der wichtigsten Garnisonen im Bezirk des 17. Armeekorps. So ist es nicht verwunderlich, dass bei der Mobilisierung 1914 bedeutende Kräfte von ihr ins Feld rückten. An ihre Stelle traten Einheiten der Landwehr, die die Kriegsgarnison bilden sollten. Doch wenig später marschierten auch sie an die Front. Im Frühjahr 1915 wurden in Thorn zwei Infanteriedivisionen zusammengestellt, während die Infrastruktur der Festung auch zur Schulung von Luftbeobachtern und Artilleristen genutzt wurde. Nach der Niederlage Deutschlands im 1. Weltkrieg kehrte nur ein Teil der Einheiten in ihre Heimatgarnison zurück, doch auch dies reichte aus, um jeglichen bewaffneten Versuch einer Besetzung der Stadt durch die Polen zu verhindern.

Słowa kluczowe: Twierdza Toruń, Garnizon Torunia, I wojna światowa, rewolucja 1918 r. w Niemczech

Keywords: Toruń Fortress, Toruń Garrison, World War I, 1918 revolution in Germany

Schlüsselwörter: Festung Thorn, Garnison Thorn, 1. Weltkrieg, Revolution von 1918 in Deutschland

\title{
Rezerwa Główna Toruń i Korpus Toruń
}

Oddziały stanowiące w czasie pokoju garnizon Twierdzy Toruń po mobilizacji wyruszyły na Wielką Wojnę w ramach XVII Korpusu Armijnego (dalej KA). Zgodnie z planami mobilizacyjnymi ich miejsce miały zająć oddziały drugorzutowe - Landwehra (dalej ldw). $\mathrm{Z}$ tego względu od 2 do 8 sierpnia 1914 r. w Szczecinie i Stralsundzie zmobi- 
lizowano 2. pułk piechoty (dalej pp) ldw. Jego sztab dotarł do Torunia już 6 sierpnia, pododdziały zaś w dniach 9-10 sierpnia. Zostały zakwaterowane na północ od twierdzy ze sztabem w Łysomicach ${ }^{1}$.

Analogiczne były losy sformowanego w Stargardzie i Kołobrzegu 9. pp ldw. Oficerów i szeregowych zmobilizowano z Pomorza Zachodniego (w tym Szczecina) oraz Meklemburgii i Westfalii. W dniach 8-10 sierpnia zawagonowano najpierw sztab pułku, a potem jego bataliony i przerzucono do Torunia. Żołnierzy zakwaterowano jednakże nie w mieście, ale w jego okolicy². Również 9-10 sierpnia do Torunia przetransportowano 19. $\mathrm{pp} \mathrm{ldw}^{3}$.

Siły te weszły w skład Rezerwy Głównej Twierdzy Torun (Hauptreserve Thorn). Po przybyciu na miejsce pułki przygotowały się do udziału $\mathrm{w}$ działaniach wojennych, uzupełniały również swoje wyposażenie ${ }^{4,5} .11$ sierpnia udały się na ćwiczenia do Łysomic ${ }^{6}$.

Zapotrzebowanie na żołnierzy było tak duże, że zdecydowano się posłać do walki dywizjon zapasowy 35. pułku artylerii polowej (dalej part. pol.) z Iławy oraz 81 part. pol. z Torunia. Zostały one połączone i w późniejszym okresie przeformowane w 35 . rezerwowy (dalej rez.) part. pol. ${ }^{7}$

Na terenie składnicy amunicji w Łysomicach 11 sierpnia $1914 \mathrm{r}$. skoncentrowano Rezerwę Główną Twierdzy Toruń, dowodzoną przez generała majora ${ }^{8}$ Maxa Philippa von Schmettau'a'. Składała się ona

\footnotetext{
${ }^{1}$ H. Herrfahrdt, E. Geißler, Königlich Preußisches Landwehr-Infanterie-Regiment König Wilhelm II. von Preußen, Oldenburg i. O. 1924, s. 11.

${ }^{2}$ Zinzow, Königlich preussisches Landwehr-Infanterie-Regiment Nr. 9, Oldenburg i.O. 1930, s. 13.

${ }^{3}$ K. Denke, K.H. Erb, Landwehr-Infanterie-Regiment Nr. 19, Oldenburg 1929, s. 16.

${ }^{4}$ Ibid.

${ }^{5}$ H. Herrfahrdt, E. Geißler, op. cit., s. 11.

${ }^{6}$ K. Denke, K. H. Erb, op. cit., s. 16.

${ }^{7}$ G. Schramek, Das Res.-Feldartillerie-Regiment Nr. 35 im Weltkriege 1914-18, Oldenburg i.O. 1925, s. 9 n.

${ }^{8} 26$ sierpnia już jako generał porucznik (zob. Der Weltkrieg 1914 bis 1918, Bd. 2, Berlin 1925, s. 361).

${ }^{9}$ W historii garnizonu toruńskiego (J. Centek, Garnizon Torunia w latach 1815 1919. Organizacja, liczebność, Rocznik Toruński, 2005, s. 208) błędnie wymieniony na tym stanowisku został generał major Fritz von Unger. W rzeczywistości był on dowód-
} 
wówczas z V Brygady Piechoty Landwehry (dalej BPLdw) (2. pp ldw i 9. pp ldw), XX BPLdw (19. pp ldw i 107. pp ldw), dwóch fortecznych pododdziałów ckm, pułku artylerii polowej Witicha (składał się z dywizjonów zapasowych 35. i 81. part. pol.) i batalionu pionierów. Do tych sił dołączyły później III baon 84. pp ldw oraz dywizjon 11. pułku artylerii pieszej (part. piesz.) ${ }^{10}$. Pod względem liczebności była to dość znaczna siła, która - zakładając stany etatowe poszczególnych oddziałów - liczyła kilkanaście tysięcy żołnierzy.

Sytuacja jednak uległa zmianie już kilka dni po przybyciu Landwehry do Torunia. $Z$ jednej strony miasto nie było bezpośrednio zagrożone rosyjskim atakiem, $\mathrm{z}$ drugiej zaś $\mathrm{w}$ Prusach Wschodnich brakowało żołnierzy. $\mathrm{Z}$ tego względu zdecydowano się posłać $\mathrm{w}$ pole rezerwy główne twierdz, w tym i Torunia. Oddziały te od 13 sierpnia 1914 r. zaczęły opuszczać twierdzę i zdążyły wziąć udział w kampanii w Prusach Wschodnich ${ }^{11}$.

W dniu 14 sierpnia 1914 r. przyszedł rozkaz, by 19. pp ldw wysłał jeden baon do Chełmży. Stamtąd pododdział wyruszył w rejon Golubia do osłony granicy z Rosją. Drugi zaś wysłano do Brodnicy ${ }^{12}$. Z kolei 2. pp ldw przerzucono 17 sierpnia do Turzna, gdzie miał się zająć osłoną granicy z Rosją ${ }^{13}$, ale już w dniach 18-20 sierpnia cały regiment operował w rejonie Włocławka ${ }^{14}$. Następnie, ze względu na sytuację $\mathrm{w}$ Prusach Wschodnich, przerzucono pułk koleją do Chełmży, a 23 sierpnia do Brodnicy, aby wziął udział w toczonych tam walkach ${ }^{15}$. Tego samego dnia trafił tam także 9. pp $1 \mathrm{dw}^{16}$.

cą Rezerwy Głównej Grudziądz (Der Weltkrieg, s. 361), a w toku kampanii w Prusach Wschodnich stał na czele oddziałów wysłanych m.in. z Gdańska, Torunia i Grudziądza w rejon Brodnica-Lidzbark-Działdowo-Nidzica-Mława (Der Weltkrieg, s. 60).

${ }^{10}$ G. Schramek, op. cit., s. 10.

${ }^{11}$ Ibid.

${ }^{12}$ K. Denke, K. H. Erb, op. cit., s. 17.

${ }^{13}$ H. Herrfahrdt, E. Geißler, op. cit., s. 11.

${ }^{14}$ Ibid., s. 12.

${ }^{15}$ Ibid.

${ }^{16}$ Zinzow, op. cit., s. 14. 
W Toruniu pozostawiono wówczas najprawdopodobniej jedynie pododdziały zapasowe jednostek garnizonu pokojowego oraz zapewne formacje Landszturmu, które nie nadawały się do wykorzystania w polu.

Sytuacja w Prusach Wschodnich była wciąż napięta i z tego względu polecono gubernatorowi Twierdzy Torun, generałowi porucznikowi Gustafowi von Dickhuth-Harrach, wzmocnienie sił niemieckich w rejonie Działdowa ${ }^{17}$. Ostatecznie w listopadzie 1914 r. stanął on na czele Korpusu Toruń (Korps Thorn $)^{18}$. W jego skład wchodziły sztaby trzech brygad piechoty, a całość stanowiła mieszaninę jednostek zapasowych z siłami Landwehry i Landszturmu. Lącznie było to 20 batalionów piechoty, 7 szwadronów kawalerii i 12 baterii artylerii ${ }^{19}$. Mimo iż liczebnie korpus przekraczał ówczesne dywizje piechoty (12 batalionów), to jednakże miał znacznie uboższą artylerię, a także mniej wartościowy materiał ludzki. Był również gorzej wyposażony. Niemcy wysłali w pole siły także z twierdz Grudziądz, Poznań czy Wrocław ${ }^{20}$.

\section{Formowanie nowych dywizji wiosną 1915 r.}

Ponieważ dotychczasowa organizacja dywizji (dwie brygady po dwa pułki piechoty każda) z jednej strony nie sprawdzała się, z drugiej zaś było zapotrzebowanie na nowe wielkie jednostki piechoty, zdecydowano się na przeprowadzenie daleko idących zmian w ich strukturze. Wydzielono z nich po jednym pułku piechoty oraz zabrano sztab jednej brygady i w ten sposób sformowano nowe. Trzon każdej z nich tworzyła od tej pory trzypułkowa brygada piechoty ${ }^{21}$.

\footnotetext{
${ }^{17}$ Der Weltkrieg 1914 bis 1918, Bd. 6, Berlin 1929, s. 102.

${ }^{18}$ W późniejszym okresie przemianowany na Korps Dickhuth (zob. Der Weltkrieg 1914 bis 1918, Bd. 7, Berlin 1931, s. 485), a ostatecznie przeformowany w 87. DP oraz 89. DP (zob. Histories of two hundred and fifty-one divisions of the German Army which participated in the war (1914-1918), Chaumont 1919, s. 564, 570).

${ }^{19}$ Der Weltkrieg 1914 bis 1918, Bd. 6, s. 459.

${ }^{20}$ Ibid., s. 459 n.

${ }^{21}$ E. von Falkenhayn, Die Oberste Heeresleitung 1914-1916 in ihren wichtigsten Entschließungen, Berlin 1920, s. 36 n.; H. Cron, Die Organisation des deutschen Heeres im Weltkriege, Berlin 1923, s. 39.
} 
Szczególna rola przypadła w tych działaniach Twierdzy Torun, gdyż to na jej terenie miano sformować, uzbroić i wyposażyć „liczne nowe dywizje" ${ }^{22}$. W praktyce zorganizowano wówczas najprawdopodobniej jedynie dwie - 105. Dywizję Piechoty (DP) oraz 107. DP.

W dniach 11 i 12 maja 1915 r. z pozycji w rejonie Bolimowa wycofano 21. pp. Żołnierze zdali karabiny, bagnety i amunicję i ruszyli na kwatery w rejonie Łowicza. W dniu 15 maja koleją oddział (bez kompanii $\mathrm{ckm}$ ) został odtransportowany do Torunia ${ }^{23}$. Tego samego dnia żołnierze dotarli na miejsce i zostali zakwaterowani $\mathrm{w}$ barakach na poligonie artyleryjskim. Wraz z 129. pp oraz 122. pp sformowali 209. BP, która z kolei weszła w skład 105. DP formowanej w tym miejscu.

W czasie pobytu 21. pp w Toruniu został on ponownie uzbrojony, wyposażony i umundurowany. Uzupełniono też jego szeregi nowymi żołnierzami. W dniach 24-25 maja pułk został zawagonowany na Podgórzu i przewieziony na Węgry ${ }^{24}$. Podobnie postąpiono ze 129. pp, który dotarł do Torunia również 15 maja $^{25}$, oraz 122. pp, przewiezionym tam trzy dni później ${ }^{26}$.

Ledwie zestawiono 105. DP, do Torunia zaczęły trafiać oddziały, które miały wejść w skład kolejnej wielkiej jednostki - 107. DP. Przed południem 3 czerwca dotarł 52. rez. pp, którego żołnierzy rozmieszczono w barakach oraz koszarach artyleryjskich (po 81. part. pol.) ${ }^{27}$. Pułk zdążył odbyć ćwiczenia strzeleckie na poligonie artyleryjskim, a rankiem 5 czerwca otrzymał rozkaz, żeby wieczorem załadować się na transport kolejowy ${ }^{28}$. Z kolei 232. rez. pp został rozmieszczony w barakach na terenie poligonu artyleryjskiego. Po uzupełnieniu sze-

\footnotetext{
${ }^{22}$ O. von Moser, Feldzugsaufzeichnungen. Als Brigade-Divisionskommandeur und als kommandierender General 1914-1918, hg. 3, Stuttgart 1928, s. 41.

${ }^{23}$ E. Hall, Kriegsgeschichte des Königlich-Preußischen Infanterie-Regiments von Borcke (4. Pomm.) Nr. 21, Zeulenroda 1930, s. $168 \mathrm{n}$.

${ }^{24}$ Ibid., s. $173 \mathrm{n}$.

${ }^{25}$ J. Steuer, Das Infanterie-Regiment Generalfeldmarschall von Mackensen (3. Westpreussisches) Nr. 129 im Weltkriege, Oldenburg-Berlin 1925, s. 109.

${ }^{26}$ H. Gnamm, Das Füsilier-Regiment Kaiser Franz Joseph von Österreich, König von Ungarn (4. Württ.) Nr. 122 im Weltkrieg 1914-1918, Stuttgart 1921, s. 66.

${ }^{27} \mathrm{H}$. Ulrich, Reserve-Infanterie-Regiment 52 im Weltkriege, Oldenburg i.O.-Berlin 1925, s. 121

${ }^{28}$ Ibid., s. 122.
} 
regów nowymi rekrutami oddział ten ruszył 6 czerwca do Galicji ${ }^{29}$. Sformowany w twierdzy sztab dywizji opuścił ją wieczorem 5 czerwca i skierował się do Galicjii ${ }^{30}$.

Artylerię obu dywizji tworzyły pułki nowe, ale powstałe przez odkomenderowanie pododdziałów oraz oficerów ${ }^{31} \mathrm{z}$ istniejących już jednostek. Mimo iż byli to żołnierze mający doświadczenie bojowe, to należało przećwiczyć ich współdziałanie.

Skompletowana 107. DP liczyła około 13000 ludzi stanu żywieniowego (300 oficerów i 10600 stanu bojowego) oraz posiadała 2700 $\mathrm{koni}^{32}$. Zestawiona parę dni wcześniej 105. DP zapewne miała zbliżoną liczebność. Można sobie zatem wyobrazić, jakim wysiłkiem dla formacji zapasowych w Toruniu było przyjęcie takiej masy ludzi, dostarczenie rekrutów do jednostek frontowych i ich względnie równomierne rozdzielenie. $\mathrm{W}$ twierdzy piechurzy otrzymywali także nową broń, naprawiano bądź wymieniano ich mundury.

\section{Stały garnizon w latach 1914-1918}

Spośród jednostek zapasowych oddziałów garnizonu w czasie pokoju w mieście stacjonował baon 21. $\mathrm{pp}^{33}$, a także najprawdopodobniej 61. pp. Z kolei baon ze 176. pp przez jakiś czas znajdował się w Chojnicach $^{34}$. Oprócz tego w Toruniu znajdowały się pododdziały tego typu z 5. rez. pp, 21. rez. pp., 49. rez. pp oraz 49. pp ldw, 2. komp. pionie-

\footnotetext{
${ }^{29}$ E. von Bartenwerffer, A. Herrmann, Das Reserve-Infanterie-Regiment Nr. 232 in Ost und West, Bd. 1, Oldenburg i.O. 1927, s. 75.

${ }^{30}$ O. von Moser, op. cit., s. $41 \mathrm{n}$.

${ }^{31}$ Przykładowo dwie baterie stacjonującego przed wojną w Toruniu 81. part. pol. oddały po plutonie, które następnie połączono w 4 baterię nowego 209 part. pol. Do nowego oddziału przeszło 3 oficerów, w tym 1 na stanowisko dowódcy dywizjonu (zob. A. Benary, Das Thorner Feldartillerie-Regiment Nr 81, Berlin 1938, s. 62).

${ }^{32}$ O. von Moser, op. cit., s. 42.

${ }^{33}$ E. Hall, op. cit., s. 592.

${ }^{34} \mathrm{~K}$. Albedyll, Soldaten und Garnisonen in Pommern und im Bezirk des 2. ArmeeKorps, Stettin 1926, s. 90; J. Centek, Wojsko niemieckie na Terenie Prus Zachodnich w latach 1918-1920, [w:] Pomorze Gdańskie i ziemia chetmińska w drodze do Niepodległej (1914-1920), pod red. Z. Girzyńskiego, I. Hałagidy, J. Kłaczkowa, Toruń 2019, s. 17.
} 
rów ldw z Korpusu Gwardii, I dywizjon rez. pułku art. pieszej gwardii, 11. part. piesz. ldw oraz dwa dywizjony (9 i 15) art. piesz. $\operatorname{ldw}^{35}$.

Również infrastruktura twierdzy była nadal wykorzystywana. Od 15 października 1916 r. działała w Toruniu Szkoła Strzelania Artylerii Pieszej (Fußartillerie Schieß-Schule) ${ }^{36}$. Natomiast na lotnisku twierdzy funkcjonowała Szkoła Obserwatorów Lotniczych w Toruniu (FliegerBeobachterschule Thorn), która podlegała istniejącemu od 6 stycznia 1917 r. pruskiemu Dowództwu Szkół Obserwatorów Lotniczych ${ }^{37}$.

\section{Garnizon Torunia po rewolucji listopadowej 1918 r.}

Już wieczorem w sobotę 9 listopada 1918 r. przed „Gubernatorstwem na Łaziennej” pojawić się miały „zgromadzenia żołnierzy”, jednak zostały one „rozbrojone” i odprowadzone „do więzienia wojskowego” przez „oddziały żandarmerii polowej” ${ }^{38}$. Nieco inaczej relacjonowała to wydarzenie „Gazeta Toruńska”, według której tego dnia wieczorem „,zgromadziły się niezliczone zastępy wojska przed gmachem gubernatorstwa wojskowego", domagając się wypuszczenia na wolność aresztowanych. „Krótko potem chmary żołnierzy szły przed gmachy więzienia wojskowego, aby przyjąć opuszczających więzienie towarzyszy"39.

Jednakże ,jeszcze w nocy gubernatorstwo i komendantura zostały zajęte”. Wszystko obyło się bezkrwawo, ponieważ „dowódcy oddziałów otrzymali z gubernatorstwa instrukcję, żeby nie stawiać zbrojnego oporu”40. Tak przedstawiała to „Die Presse”. W rzeczywistości wątpić jednak należy, czy wydanie innych rozkazów zmieniłoby sytuację. Przy całym zamieszaniu doszło do przypadków plądrowania - głównie zapasów żywności z Urzędu Prowiantowego, rzeźni czy fabryki konserw. Okradziono także sprzedawców papierosów ${ }^{41}$.

\footnotetext{
${ }^{35}$ K. Albedyll, op. cit., s. 101; J. Centek, Garnizon Torunia, s. 208.

${ }^{36}$ H. Cron, op. cit., s. 190; J. Centek, Garnizon Torunia, s. 208.

${ }^{37}$ H. Cron, op. cit., s. 194.

${ }^{38}$ Die Entwickelung der Dinge in Thorn, Die Presse. Ostmärkische Tageszeitung. Anzeiger für Stadt und Land (Thorner Presse), 12 XI 1918, s. 2.

${ }^{39}$ Ruchy rewolucyjne w Toruniu, Gazeta Toruńska, 12 XI 1918, s. 2.

${ }^{40}$ Die Entwickelung der Dinge in Thorn, s. 2.

${ }^{41}$ Ibid.; Ruchy rewolucyjne w Toruniu, s. 2.
} 
Rankiem w niedzielę 10 listopada 1918 r. w Toruniu pojawiły się informacje, że władzę w mieście przejęła Rada Robotników i Żołnierzy, która będzie się starała zachować porządek. Poszczególne oddziały wydelegowały swoich przedstawicieli do rady, która zebrała się w Dworze Artusa ${ }^{42}$.

„W porozumieniu z radą żołnierską" utworzono straż obywatelską, która miała wspierać jej posterunki w utrzymaniu porządku w mieście. Członkowie rady mieli czerwone opaski na ramionach z pieczęcią, a członkowie straży obywatelskiej „kokardy w biało-czerwonych barwach". Poszczególne dzielnice wyznaczyły mężów zaufania ${ }^{43}$. Wzywano również robotników, by wybierali po 1-2 osoby z poszczególnych zakładów ${ }^{44}$.

Jak pisała „Gazeta Toruńska”, Rada Robotników i Żołnierzy „porozstawiała $\mathrm{w}$ całem mieście silne posterunki wojskowe" oraz zarządziła godzinę policyjną od 18:00 do 5:00 rano. W ten sposób przywrócono w Toruniu spokój ${ }^{45}$.

W poniedziałek, 11 listopada, ukazało się wspólne obwieszczenie Gubernatorstwa i Rady Żołnierskiej, że będą współdziałać, „a dotychczasowy wojskowy porządek i podporządkowanie" będą istnieć dalej „na służbie, ale nie poza służbą,46.

Zarządzono również, że „broń strzelecka może być noszona tylko w służbie wartowniczej”" ${ }^{\prime 7}$. Było to posunięcie słuszne, gdyż grupy żołnierzy próbowały ponownie splądrować fabrykę konserw oraz gorzelnię, zostały jednakże odparte przez wartowników „przy użyciu karabinów maszynowych" 48 .

Wśród Niemców szybko obudziły się nastroje nacjonalistyczne. 10 listopada 1918 r. w Toruniu ,jacyś niesumienni podżegacze” rozsiewali „wśród żołnierzy niemieckich” pogłoski, ,jakoby Polacy toruńscy w nocy z niedzieli na poniedziałek zamierzali wystąpić przeciw

${ }^{42}$ Die Entwickelung der Dinge in Thorn, s. 2.

${ }^{43}$ Ibid.

${ }^{44}$ Aufruf an die werktägige Bevölkerung Thorns, Die Presse, 14 XI 1918, s. 4.

${ }^{45}$ Ruchy rewolucyjne $w$ Toruniu, s. 2.

${ }^{46}$ Die Entwickelung der Dinge in Thorn, s. 3.

${ }^{47}$ Ibid.

${ }^{48}$ Ibid. 
radzie robotników i żołnierzy". Apelowano przy tym o zachowanie spokoju i informowano, że „w poniedziałek było w pogotowiu wojennem 15000 żołnierzy, nawet artyleria, a niemniej lotnicy pełnili służbę wywiadowczą"49. Podana liczba została prawdopodobnie przesadzona, by wywrzeć większe wrażenie na czytelnikach. W Toruniu i najbliższej okolicy prawdopodobnie nie znajdowały się takie siły, które byłyby gotowe do walki.

Z kolei wiadomość o powstaniu partii założonej przez Polaków przyjęto stwierdzeniem, że trzeba ją zniszczyć, gdyż „tu są tylko Niemcy i tylko [oni] być mogą"50. Polacy również byli zdecydowani zamanifestować swoją obecność. Nastąpiło to jednak dopiero po kilku dniach. 17 listopada zorganizowali w Toruniu uroczysty wiec, podczas którego odśpiewano Boże coś Polskę; „Gazeta Toruńska” nazwała tę pieśń „hymnem narodowym” ${ }^{2}$.

Wacław Hulewicz, który przebywał wówczas w szpitalu wojskowym w Toruniu (symulując zapalenie stawu kolanowego), wspominał po latach: ,aż dnia pewnego doszły mnie z korytarza i podwórka niezwykłe szuranie i szmery. Wyjrzałem przez okno. Spostrzegłem »chorych« żołnierzy szybko biegnących ku furcie szpitala, a na bruku podwórka liczne porzucone kule i protezy. Działo się to 11 listopada. Sąsiadował ze mną (równie chory, jak ja) lejtnant Leon Bogusławski, który radośnie [...] objaśnił: Kapitulacja - rewolucja w Berlinie - koniec wojny” ${ }^{\text {52 }}$. „Ale cóż? - Oficerom nawet ze szpitala, uciec samowolnie nie wypadało. Było nas pięciu, wszyscy Polacy. Uradziliśmy, że poczekamy na lekarza $[\ldots]$ poprosiliśmy go, by nas formalnie wypisał i zwolnił ze szpitala. Doktór był mocno zdenerwowany i nie chciał się zgodzić na naszą sugestię" ${ }^{\circ 3}$. „Przy furcie szpitalnej - mimo rewolucji - nadal pełnił służbę posterunek. Nawet przepisowo zasalutował oficera, lecz mi oznajmił, że na skutek zarządzenia Rady Żołnierskiej obecnej władzy - oficerowie winni z munduru usunąć dystynkcje.

${ }^{49}$ Polacy w Toruniu, Gazeta Toruńska, 12 XI 1918, s. 1 n.

${ }^{50}$ Die Entwickelung der Dinge in Thorn, s. 3.

${ }^{51}$ Olbrzymi wiec polski w Toruniu, Gazeta Toruńska, 19 XI 1918, s. 1.

${ }^{52}$ W. Hulewicz, Czy zawsze wspomnieć miło?, Szczecin 1971, s. 112, mps w archiwum prywatnym autora.

${ }^{53}$ Ibid. 
Wiem o wypadku, że pewien niemiecki oficer oparł się temu zarządzeniu i w obronie swego honoru odebrał sobie życie. Ja zaś na tę propozycję chętnie się zgodziłem. Po chwili mój mundur został przy pomocy wartownika pozbawiony epoletów, a czapka pruskiej kokardy”,54.

12 listopada 1918 r. na łamach „Gazety Toruńskiej” ukazało się Ogłoszenie, w którym informowano, że z dniem 10 listopada $1918 \mathrm{r}$. „Gubernatorstwo uznaje utworzoną w Toruniu radę żołnierską i jej wydział i udziela władzom fortecy i komendantom wojska odpowiednich wskazówek. Rada żołnierska uznaje ze swej strony organizację wojskową, która w interesie ogółu - wojska i ludności cywilnej - pod kontrolą rady żołnierskiej dalej istnieje stosownie do rozporządzenia kanclerza Eberta z dnia 9 bm., oraz władze i urzędników ojczyzny. Aby to upewnić, pracuje ściślejszy wydział z 3 osób rady żołnierskiej stale $\mathrm{z}$ gubernatorstwem. Czynności urzędowe gubernatorstwa tenże wydział ściślejszy będzie wspólnie podpisywał. Rada żołnierska i jej wydział wydawają swe rozporządzenia ze współudziałem gubernatorstwa. Wszystkie ogłoszenia są wspólne. U wojska utworzone zostaną rady wojskowe, które są czynne we wspólnej pracy z dotychczasową organizacją wojskową" ${ }^{\text {55 }}$. Zostało ono podpisane zapewne przez ów trzyosobowy ściślejszy wydział Rady Żołnierskiej, niemniej jednak po stronie Gubernatorstwa sygnował je jedynie jeden z oficerów - porucznik Starck ${ }^{56}$.

Koniec wojny oznaczał masy zdemobilizowanych mężczyzn, którzy nie mieli pracy. $Z$ zachodu Niemiec zwalniano robotników pochodzących $\mathrm{z}$ terenów przedwojennej Rosji, którzy nierzadko z całymi rodzinami przejeżdżali przez Toruń do swych domów ${ }^{57}$. Mieszkańcom miasta także doskwierało bezrobocie, a do tamtejszej Rady Żołnierskiej napływało tyle próśb o pomoc $\mathrm{w}$ znalezieniu zatrudnienia, że zdecydowała się ona na zamieszczenie informacji, żeby w tych sprawach udawać się „do miejskiego wykazu pracy”"58.

\footnotetext{
${ }^{54}$ Ibid.

${ }^{55}$ Ogtoszenie, Gazeta Toruńska, 12 XI 1918, s. 2.

${ }^{56}$ Ibid.

${ }^{57}$ Odezwa!, Gazeta Toruńska, 29 XI 1918, s. 2.

${ }^{58}$ Obwieszczenie, Gazeta Toruńska, 29 XI 1918, s. 2.
} 
Dyscypliny nie udało się całkowicie zaprowadzić nawet pod koniec 1918 r. „Die Presse” pisała, że „w ostatnim czasie” żołnierze przeprowadzili „przeszukania domów i konfiskaty żywności i broni” bez „uprawnień do tego". Dla zapobieżenia temu procederowi sformowano do przeszukań kompanię bezpieczeństwa (Sicherheitskompanie), której członkowie mieli czerwone opaski $\mathrm{z}$ numerami oraz dokumenty wystawione przez policję z właściwym numerem. Żołnierzy, którzy bez tego chcieliby przeprowadzać konfiskaty, stawiano na równi z plądrującymi. Zakazano przeprowadzania przeszukań w nocy ${ }^{59}$.

Napięta sytuacja w mieście panowała także w późniejszym okresie. Zgodnie z obwieszczeniem ze stycznia 1919 r. wprowadzono obowiązek legitymowania się dla wszystkich przybywających na dworzec kolejowy lub poruszających się po moście. Wydawano specjalne zezwolenia na pobyt $\mathrm{w}$ twierdzy na trzy dni, „dhuższego zezwolenia udzielać może kierownik policji”. Niemającym stałego zamieszkania i bezrobotnym nakazano natychmiastowe opuszczenie Torunia ${ }^{60}$.

\section{Powrót jednostek garnizonu pokojowego z frontu}

W dniu 23 listopada 1918 r. wycofujący się z frontu zachodniego 21. pp w rejonie Hindershausen przekroczył granicę niemiecko-belgijską $^{61}$. Droga do macierzystego garnizonu była jednak daleka. Jeszcze przed powrotem, gdy 14 grudnia Oberste Heeresleitung wezwało do formowania jednostek Grenzschutz-Ost, „do dyspozycji oddał się prawie cały pułk" ${ }^{\prime 2} .18$ grudnia ze względu na "groźną sytuację na wschodzie" Niemcy zamierzali przerzucić 21. pp jak najszybciej do macierzystego garnizonu. W południe zawagonowano sztab pułku, I baon, 6. kompanię oraz 2. kompanię ckm. Reszta regimentu znalazła się w transporcie wieczorem. Obydwa rzuty pojechały linią kolejową Marburg - Berlin - Piła - Toruń. Drugi z nich został zatrzymany przez Polaków w Nakle, jednak ostatecznie go zwolniono ${ }^{63}$.

\footnotetext{
${ }^{59}$ Bekanntmachung, Die Presse, 21 XII 1918, s. 3.

${ }^{60}$ Obwieszczenie, Gazeta Toruńska, 21 I 1919, s. 9.

${ }^{61}$ E. Hall, op. cit., s. 589.

${ }^{62}$ Ibid., s. 591.

${ }^{63}$ Ibid., s. 591 n.
} 
Pierwszy transport 21. pp dotarł do Torunia dopiero 21 grudnia przed godziną 12:00. Drugiego zaś spodziewano się o 22:00 ${ }^{64}$. W historii 21. pp znalazł się opis sytuacji w Toruniu z końca grudnia 1918 r.: „[...] dzikie postacie z rozpiętymi płaszczami, karabiny z wylotem na dół, z czerwonymi opaskami na ramionach i kokardami na czapkach, wędrują po mieście, podają, że troszczą się o spokój i porządek" ${ }^{, 65}$. Oddział odmówił przy tym złożenia broni, czego domagała się miejscowa Rada Żołnierska. Po defiladzie przed pomnikiem Kopernika pułk został powitany przez burmistrza Hassego ${ }^{66}$.

Do szeregów 21. pp mieli rzekomo „licznie zgłaszać się ochotnicy", ale raczej nie w takiej liczbie, w jakiej chciałaby to przedstawić historia pułku. Do podniesienia stanu osobowego konieczne było także ściągnięcie kompanii ochotniczych z Gdańska, co spowodowało powiększenie oddziału do „blisko 3000 ludzi”. Wzmocniony ochotnikami 21. pp obsadził południowy odcinek Twierdzy Torun i „skutecznie bronił go przeciwko wszystkim atakom Polaków. Dowódcą odcinka był, przy zachowaniu kierowania pułkiem, płk Lüdecke" ${ }^{, 67}$. Warto podkreślić, że Polacy nie mieli zamiaru atakować Torunia, zdając sobie sprawę z niemożliwości jego zbrojnego opanowania z powodu braku ciężkiej artylerii, bez której zdobycie nawet przestarzałych fortów nie było możliwe. Wprawdzie 5 stycznia 1919 r. doszło do wymiany ognia między siłami polskimi a żołnierzami 21. pp w rejonie Opoczek (wówczas Klein Opok), jednakże z pewnością nie była to próba zdobycia twierdzy.

W dniu 13 marca 1919 r. rozwiązano 21. pp i przekształcono go w Pułk Ochotniczy von Borckego Nr 21 (Freiwilligen-Regiment von Borcke Nr. 21) ${ }^{68}$. W październiku 1919 r. III baon tego regimentu został skierowany na front $w$ Inflantach, a reszta pododdziałów, po wycofaniu z Torunia, zajęła pozycje na nowej granicy Rzeszy w rejonie Biały Bór (koło Szczecinka) - Człuchów ${ }^{69}$.

\footnotetext{
${ }^{64}$ Lokalnachrichten, Die Presse, 22 XII 1918, s. 2.

${ }^{65}$ E. Hall, op. cit., s. 592.

${ }^{66}$ Ibid.

${ }^{67}$ E. Hall, op. cit., s. 592 n.

${ }^{68}$ Ibid.

${ }^{69}$ Ibid., s. 657.
} 
Pozostałe regimenty piechoty toruńskiego garnizonu nie wróciły do niego po zawarciu zawieszenia broni. Już 26 listopada w Kolonii załadowano do transportu kolejowego 61. pp. Następnie przez Düsseldorf - Bremę - Hamburg - Szczecin jechał on przez trzy dni na wschód. Jeżeli wierzyć historii pułkowej, żołnierze siedzieli w nieoświetlonych i nieogrzewanych wagonach i do końca nie znali miejsca przeznaczenia. Okazało się nim Wąbrzeźno, gdzie dotarli rankiem 29 listopada 1918 r. Odcinek osłaniany przez 61. pp rozciągał się od obszaru podległego gubernatorowi Torunia do rejonu Brodnicy. Pułk na krótko wkroczył do Torunia w kwietniu 1919 r., przyjęty entuzjastycznie przez miejscowych Niemców. Po defiladzie i powitaniu przez burmistrza oddział wrócił w rejon Wąbrzeźna ${ }^{70}$. Jego szeregi uzupełnione zostały poprzez werbunek ochotników, przede wszystkim na Pomorzu Tylnym. Latem 1919 r. został przekształcony w 73. Pułk Piechoty Reichswehry (Reichswehr-Infanterie-Regiment Nr. 73), który rozwiązano w lutym $1920 \mathrm{r}^{71}$

Z kolei 176. pp dopiero 22 listopada przekroczył granicę niemiecką na południe od Akwizgranu ${ }^{72}$. Został on 28 listopada zawagonowany w Kolonii i przerzucony transportem kolejowym nie do macierzystego garnizonu w Toruniu, ale do Brodnicy, do której wkroczył 1 grudnia $1918 \mathrm{r}^{73}$

Również pułki artylerii polowej nie wróciły bezpośrednio do Torunia. W dniu 21 listopada 1918 r. 81. part. pol. przekroczył granicę niemiecką w rejonie Trieru i dopiero w styczniu 1919 r. przerzucony został do Prus Zachodnich ${ }^{74}$. We wsi Mareza pod Kwidzynem na początku lutego 1919 r. udało się Niemcom zestawić ochotniczy dywizjon artylerii, który przerzucono w okolice na północ od Torunia ${ }^{75}$. Dopiero pod koniec maja 1919 r. ochotniczy dywizjon, który powstał

\footnotetext{
${ }^{70}$ von Keiser, Geschichte des Inf.-Regts. v. d. Marwitz (8. Pomm.) Nr. 61 im Weltkriege 1914-1918, Berlin 1928, s. 358 n.

${ }^{71}$ Ibid., s. 360.

${ }^{72}$ W. Preusser, 9. Westpreußische Infanterie-Regiment Nr. 176 im Weltkrieg, Berlin 1931, s. 305.

${ }^{73}$ Ibid.

${ }^{74}$ A. Benary, op. cit., s. 168.

${ }^{75}$ Ibid.
} 
na bazie 81. part. pol., został zakwaterowany w koszarach macierzystego regimentu $\mathrm{w}$ mieście. Jednakże nie doszło do starć z Polakami, a w sierpniu wycofano go na Pomorze ${ }^{76}$.

Również 35. rez. part. pol. nie wrócił do Torunia, skąd przynajmniej w części się wywodził. Oddział ten już 15 listopada musiał zdać działa, a dopiero na początku stycznia 1919 r. został, w trzech rzutach, zawagonowany i po trzech dniach podróży dotarł do Iławy, gdzie go rozwiązano ${ }^{77}$.

Z kolei pułki Landwehry, przewidywane w planie mobilizacyjnym jako wojenny garnizon Twierdzy Toruń i stanowiące jej Rezerwę Główną, zakończyły swoje istnienie po powrocie do Niemiec. Wyjątkiem był 9. pp ldw, który wiosną 1918 r. przerzucono na front zachodni. Krótko po dotarciu na miejsce oddział został rozwiązany, a jego żołnierze uzupełnili szeregi innych regimentów ${ }^{78}$. Natomiast $19 . \mathrm{pp}$ ldw po zakończeniu działań wojennych został przetransportowany do Bolesławca, gdzie od połowy grudnia 1918 r. do początków lutego 1919 r. następowała jego demobilizacja ${ }^{79}$. Również 2. pp ldw, który pod koniec wojny działał na Ukrainie i sformował nawet jednostkę ochotniczą, nie znalazł się nawet $\mathrm{w}$ pobliżu Torunia. Po wycofaniu z Ukrainy, przez Brześć Litewski-Białystok-Osowiec, dotarł do Prus Wschodnich, skąd ostatecznie trafił do Szczecina, gdzie został rozwiązany $^{80}$.

Spośród jednostek tworzących wcześniej Korpus Toruń 87. DP zakończyła działania wojenne na froncie zachodnim, jednakże jej regimenty nie wróciły do Torunia, ale zostały w styczniu 1919 r. rozwiązane w Kościanie (345. pp), Bolesławcu (346. pp) oraz Kołobrzegu (347. $\mathrm{pp}^{81}$. Z kolei 89. DP w listopadzie 1918 r. znajdowała się w Rumunii,

\footnotetext{
${ }^{76}$ Ibid., s. 169.

${ }^{77}$ G. Schramek, op. cit., s. 208.

${ }^{78}$ Zinzow, op. cit., s. 137.

${ }^{79}$ K. Denke, K.H. Erb, op. cit., s. 291 n.

${ }^{80}$ H. Herrfahrdt, E. Geißler, op. cit., s. 109 n.

${ }^{81}$ Ruhmestahle unserer alten Armee, Leipzig 1925, s. 153; J. Kraus, Handbuch der Verbände und Truppen des deutschen Heeres 1914-1918, Tl. VI, Bd. 1, Wien 2007,
} s. $308-310$. 
skąd przez Węgry wracała do Niemiec ${ }^{82}$. Z jej oddziałów do Torunia dotarły 31 grudnia 1918 r. resztki 375. pp, gdyż żołnierzy pochodzących $\mathrm{z}$ innych części Rzeszy zwalniano po drodze ${ }^{83}$. Losu pozostałych oddziałów nie udało się niestety ustalić.

W styczniu 1919 r. gubernatorem twierdzy był generał major Wilhelm von Groddeck ${ }^{84}$. W chwili wybuchu wojny był dowódcą 36. part. pol. w Gdańsku, wojnę zakończył na stanowisku dowódcy 208. DP w stopniu generała majora ${ }^{85}$. Do Torunia musiał zatem trafić nie wcześniej niż jesienią $1918 \mathrm{r}$. Niestety, na obecnym etapie badań nie udało się ustalić wojennych gubernatorów twierdzy, którzy sprawowaliby to stanowisko od wyruszenia generała Dickhuth-Harracha na front w listopadzie 1914 r. do nominacji von Groddecka, zapewne cztery lata później.

Podpisany przez Niemców traktat wersalski oddawał Torun, wraz z przeważającą częścią okręgu XVII KA, Polsce. W takiej sytuacji przy formowaniu nowej niemieckiej Reichsheer ${ }^{86}$ oddziały $\mathrm{z}$ okręgu XVII KA zostały połączone $\mathrm{z}$ tymi z IX KA ${ }^{87}$. Tradycje wszystkich jednostek regularnych z 1914 r. były kultywowane przez poszczególne kompanie, baterie i szwadrony.

\section{Niemieckie siły ochotnicze w rejonie Torunia}

Spośród tworzonych przez Grenzschutz-Ost jednostek ochotniczych często trudno jednoznacznie wskazać, które z nich trafiły do Prus Za$\operatorname{chodnich}^{88}$, a co dopiero powiązać je z garnizonem Torunia. Niemniej jednak z pewnością z twierdzą związany był Forteczny Korpus Ochotniczy Toruń (Festungs-Freikorps-Thorn), sformowany w marcu 1919 r. ${ }^{89}$,

\footnotetext{
${ }^{82}$ Ruhmeshalle, s. 154.

${ }^{83}$ [A. Huth], Regiments Geschichte I.R. 375, Bd. 2, b.m. i r., s. Z 15.

${ }^{84}$ Obwieszczenie, Gazeta Toruńska, 21 I 1919, s. 9.

${ }^{85}$ Ehren-Rangliste des ehemaligen Deutschen Heeres, Berlin 1926, s. 497.

${ }^{86}$ Szerzej zob. J. Centek, Reichsheer ery Seeckta (1921-1926), Warszawa 2010.

${ }^{87}$ E. Hall, op. cit., s. 657.

${ }^{88}$ Niemieckie jednostki ochotnicze, które operowały w prowincji Prusy Zachodnie zob. J. Centek, Wojsko niemieckie, s. 24-26.

${ }^{89}$ R. Thoms, S. Pochanke, Handbuch zur Geschichte der deutschen Freikorps, München 2001, s. 77.
} 
a także Ochotniczy 11. Pułk Artylerii Pieszej (Freiwilligen Fußartillerie Regiment 11$)^{90}$.

Kluczową jednakże jednostką Grenzschutzu, która nie stacjonowała wprawdzie bezpośrednio w Toruniu, jednakże mogła w razie potrzeby być użyta do obrony miasta, był Korpus Ochotniczy Roßbacha (Freikorps Roßbach), znany również jako Oddział Szturmowy Roßbacha (Sturmabteilung Roßbach). Powstał on 21 listopada 1918 r. i na przełomie lat 1918 i 1919 r. znajdował się w Prusach Zachodnich, zanim został skierowany do Inflant ${ }^{91}$.

Jak notowała „Gazeta Toruńska”, w Grenzschutzu zdarzały się pro-

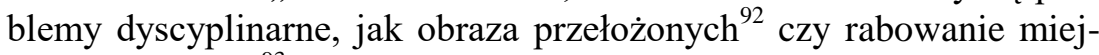
scowej ludności ${ }^{93}$, przeprowadzane czasem pod pretekstem poszukiwania broni ${ }^{94}$. Najprawdopodobniej to ta formacja dokonała także rekwizycji 300 koni, z których „część zdołano” odzyskać ${ }^{95}$. „Gazeta Toruńska” pisała także, iż „Grencszucu nie cierpią najbardziej ci żołnierze niemieccy, którzy zrobili rewolucyę i stąd uważają się za zbawców i wybawicieli ludu niemieckiego z pod dawnego dawnego jarzma i militaryzmu, a tworzone oddziały Grencszucu wysuwa reakcya jako elitę i odnowicieli dawnej potęgi militarnej w Niemczech z uszczerbkiem dla wolnościowych kadr republikańskich. Robotnik i lud tak polski jak niemiecki rozgoryczony jest dla tego, że z nastaniem Grencszucu zaczęto wywozić masowo żywność - mąkę, kawę i inne artykuły spożywcze, których na miejscu brak" 96 .

Rekrutując do Grenzschutzu podkreślano, że ochotnicy otrzymają jedzenie takie, jak podczas wojny, przez co było „daleko lepsze, jak wyżywienie wojska republikańskiego. Robotnicy zaś niemieccy, jak polscy, nienawistnem okiem w tych ciężkich czasach, w których racyę żywnościową się skraca dla nich, patrzą na zachwalanie lepszem od-

\footnotetext{
${ }^{90}$ Ibid., s. 105.

${ }^{91}$ Ibid., s. 86; J. Centek, Skład garnizonu Grudziadza 1773-1920, Rocznik Grudziądzki 2005, t. 16, s. 44.

${ }_{92}$ O karność w Grencszucu, Gazeta Toruńska, 23 III 1919, s. 1.

${ }^{93}$ Polska, Gazeta Toruńska, 22 III 1919, s. 3.

${ }^{94}$ Polożenie w Prusach Zachodnich, Gazeta Toruńska, 21 II 1919, s. 1.

${ }^{95}$ Gazeta Toruńska, 1 VII 1919, s. 1.

${ }^{96}$ Czemu Grencszuc tak znienawidzony?, Gazeta Toruńska, 21 II 1919, s. 2.
} 
żywianiem wstępowania do Grencszucu"97. Lepszy prowiant, wraz z żołdem wynoszącym cztery marki dziennie, był dla wielu poważną zachętą do wstępowania w szeregi tej formacji. Przy czym, co nawet przyznają sami Niemcy w historiach pułków, przyciągało to również ochotników, którzy nie kierowali się żadnymi pobudkami patriotycznymi ${ }^{98}$.

Gdy w lutym 1919 r. do Chełmży dotarł oddział porucznika Roßbacha, według relacji „Gazety Toruńskiej” władze miasta zostały powiadomione telegraficznie, że za trzy dni przybędzie oddział Grenzschutzu. Burmistrz zorganizował w takiej sytuacji naradę Magistratu i Rady Robotniczej, ale w trakcie spotkania przybył por. Roßbach, który poinformował, że „stoi z oddziałem swoim przed miastem z zamiarem wkroczenia do miasta". Zebrani zaprotestowali i wysłali telegramy do „komendy głównej do Gdańska [prawdopodobnie dowództwa XVII Okręgu Korpusu - J.C.] i do Rządu głównego do Berlina, a od p. Rossbacha zażądano, by powstrzymał wkroczenie do miasta aż do chwili nadejścia odpowiedzi z Gdańska lub Berlina [...] Na to odpowiedział p. Rossbach, że on ma rozkaz wkroczenia do Chełmży i na telegraficzną odpowiedź czekać nie będzie" ${ }^{99}$.

Tymczasem thum rozbroił żołnierzy czekających w aucie pod ratuszem oraz osadził ich, razem z Roßbachem, w areszcie. Według doniesień „Gazety Toruńskiej” Niemcy mieli ostrzelać miasto trzema pociskami artyleryjskimi, zabijając troje dzieci. Niemcy zażądali także wydania wszelkiej broni, a i tak wkraczając do miasta mieli strzelać $\mathrm{z}$ „karabinów i kulomiotów wprost w ulice do przechodniów”, zabijając 8 i raniąc 15 osób. Wprowadzono stan wyjątkowy i rozpoczęto aresztowania Polaków ${ }^{100}$. Zarządzenie to zostało wydane najprawdopodobniej przez sztab 35. DP, który w drugiej dekadzie lutego $1919 \mathrm{r}$. rozciągnął je także na sąsiednie miejscowości ${ }^{101}$.

\footnotetext{
${ }^{97}$ Ibid.

${ }^{98}$ J. Centek, Kawaleria niemiecka w latach 1918-1921, [w:] Do szarży marsz, marsz... Studia z dziejów kawalerii, pod red. A. Smolińskiego, t. 1, Toruń 2010, s. 501.

${ }^{99}$ Straszne zabójstwo w Chetmży, Gazeta Toruńska, 26 II 1919, s. 2.

${ }^{100}$ Ibid., s. 2 i n.

${ }^{101}$ Położenie w Prusach Zachodnich, Gazeta Toruńska, 13 II 1919, s. 1.
} 
O antypolskim nastawieniu żołnierzy niemieckich jednostek ochotniczych doskonale świadczy wydarzenie opisane na łamach „Gazety Toruńskiej”. 1 stycznia 1920 r. żołnierze 21. pp trzykrotnie wdzierali się na salę, w której odbywało się przedstawienie, wykrzykując ,precz z Polakami, precz z psami" ${ }^{\text {,102 }}$.

\section{Podsumowanie}

W czasie wojny Toruń został ogołocony nawet z jednostek, które miały stanowić jego wojenny garnizon, gdyby twierdza była zagrożona przez wojska rosyjskie. Pozostawiono także nie wszystkie bataliony zapasowe pułków garnizonu pokojowego. Niemniej jednak infrastruktura forteczna odegrała istotną rolę $\mathrm{w}$ formowaniu nowych jednostek w czasie wojny. Wykorzystano ją też do szkolenia artylerzystów, jak i lotników.

Po zakończeniu działań wojennych garnizon był zdemoralizowany, o czym najlepiej świadczą przypadki plądrowania czy nielegalnych rekwizycji, jakich dopuszczali się żołnierze. $Z$ tego względu nie stanowił on zbytniej wartości bojowej, zwłaszcza że tylko podczas warty można było mieć bron. Również większość pułków, które wyruszyły na wojnę z Torunia, nie wróciła do niego.

Spadek liczebności garnizonu, jak i jego wartości bojowej nie oznaczał jednak, że twierdzę dałoby się łatwo opanować w przypadku polskiego ataku. Wydaje się, że takie zagrożenie z jednej strony zmotywowałoby również zdemoralizowanych żołnierzy do walki, a z drugiej - w pobliżu znajdowały się siły Korpusu Ochotniczego Roßbacha, które szybko przyszłyby z odsieczą. Dodatkowo nawet przestarzałe forty stanowiłyby dla Polaków praktycznie niemożliwą do pokonania przeszkodę, gdyż nie dysponowali oni nowoczesną artylerią ciężką.

${ }^{102}$ Napaść żolnierzy na Polaków, Gazeta Toruńska, 6 I 1920, s. 1. 


\section{Bibliografia}

\section{Źródła}

Niepublikowane

Hulewicz W., Czy zawsze wspomnieć miło?, Szczecin 1971 (mps w archiwum prywatnym autora).

Publikowane

Falkenhayn E. von, Die Oberste Heeresleitung 1914-1916 in ihren wichtigsten Entschließungen, Berlin 1920.

Histories of two hundred and fifty-one divisions of the German Army which participated in the war (1914-1918), Chaumont 1919.

Moser O. von, Feldzugsaufzeichnungen. Als Brigade-Divisionskommandeur und als kommandierender General 1914-1918, wyd. 3, Stuttgart 1928.

Prasa

„Gazeta Toruńska” 1918, 1919

„Die Presse. Ostmärkische Tageszeitung. Anzeiger für Stadt und Land (Thorner Presse)" 1918.

Opracowania

Albedyll K., Soldaten und Garnisonen in Pommern und im Bezirk des 2. Armee-Korps, Stettin 1926.

Bartenwerffer E. von, Herrmann A., Das Reserve-Infanterie-Regiment Nr. 232 in Ost und West, Oldenburg i.O 1927, t. 1.

Benary A., Das Thorner Feldartillerie-Regiment Nr 81, Berlin 1938.

Centek J., Garnizon Torunia w latach 1815-1919. Organizacja, liczebność, Rocznik Toruński, 2005, s. 191-213.

Centek J., Kawaleria niemiecka w latach 1918-1921, [w:] Do szarży marsz, marsz... Studia z dziejów kawalerii, pod red. A. Smolińskiego, t. 1, Toruń 2010, s. 479-547.

Centek J., Reichsheer ery Seeckta (1921-1926), Warszawa 2010.

Centek J., Skład garnizonu Grudziądza 1773-1920, Rocznik Grudziądzki, 2005, s. 31-44.

Centek J., Wojsko niemieckie na Terenie Prus Zachodnich $w$ latach 19181920, [w:] Pomorze Gdańskie i ziemia chetmińska w drodze do Niepodległej (1914-1920), pod red. Z. Girzyńskiego, I. Hałagidy, J. Kłaczkowa, Toruń 2019, s. 9-13.

Cron H., Die Organisation des deutschen Heeres im Weltkriege, Berlin 1923.

Denke K., Erb K. H., Landwehr-Infanterie-Regiment Nr. 19, Oldenburg 1929. 
Ehren-Rangliste des ehemaligen Deutschen Heeres, Berlin 1926.

Gnamm H., Das Füsilier-Regiment Kaiser Franz Joseph von Österreich, König von Ungarn (4. Württ.) Nr. 122 im Weltkrieg 1914-1918, Stuttgart 1921.

Hall E., Kriegsgeschichte des Königlich-Preußischen Infanterie-Regiments von Borcke (4. Pomm.) Nr 21, 1931.

Herrfahrdt H., Geißler E., Königlich Preußisches Landwehr-Infanterie-Regiment König Wilhelm II. von Preußen, Oldenburg i. O. 1924.

[Huth A.], Regiments Geschichte I.R. 375, Bd. 2, b.m. i r.

Keiser von, Geschichte des Inf.-Regts. v. d. Marwitz (8. Pomm.) Nr. $61 \mathrm{im}$ Weltkriege 1914-1918, Berlin 1928.

Kraus J., Handbuch der Verbände und Truppen des deutschen Heeres 19141918, Tl. VI, Bd. 1, Wien 2007, s. 308-310.

Preusser W., 9. Westpreußische Infanterie-Regiment Nr. 176 im Weltkrieg, Berlin 1931.

Ruhmestahle unserer alten Armee, Leipzig 1925.

Schramek G., Das Res.-Feldartillerie-Regiment nr. 35 im Weltkriege 1914-18, Oldenburg i.O. 1925.

Steuer J., Das Infanterie-Regiment Generalfeldmarschall von Mackensen (3. Westpreussisches) Nr. 129 im Weltkriege, Oldenburg-Berlin 1925.

Thoms R., Pochanke S., Handbuch zur Geschichte der deutschen Freikorps, München 2001.

Ulrich H., Reserve-Infanterie-Regiment 52 im Weltkriege, Oldenburg i.O.- Berlin 1925.

Der Weltkrieg 1914 bis 1918, Bd. 2, Berlin 1925; Bd. 6, Berlin 1929; Bd. 7, Berlin 1931.

Zinzow, Königlich preussisches Landwehr-Infanterie-Regiment Nr. 9, Oldenburg i.O 1930.

\section{Toruń Military Reserve and Toruń Corps}

The units constituting the garrison of the Torun Fortress in the times of peace after mobilization set off for the Great War as part of the 17th Army Corps (hereinafter AC). According to the mobilization plans, they were to be replaced by secondary troops - Landwehr. For this reason, from 2 August to 8 August 1914, the 2nd Infantry Regiment (hereinafter IR) of the Polish Army was mobilized in Szczecin and Stralsund. Its staff arrived in Torun on 6 August, while subunits 